\title{
LIGHTING INSTALATIONS FOR PLANTS LIGHTCULTURE WITH ADDITIONAL IMPULSIVE RADIATION
}

\author{
Mariia Kotyk $^{1}$; Volodimir Andriychuk ${ }^{1}$; Andriy Herts ${ }^{2}$ \\ ${ }^{I}$ Ternopil Ivan Puluj National Technical University, Ternopil, Ukraine \\ ${ }^{2}$ Ternopil Volodymyr Hnatyuk National Pedagogical University, \\ Ternopil, Ukraine
}

\begin{abstract}
Summary. Results of research of plants radiation conditions in enclosed soil are presented in the paper, block diagram of instalation for measuring of energetic parameters of impulsive light sources (luminary) is shown, energysaving illuminators are chosen. Experimental researches were held with the usage of minigreenhouses type of «Flora». Selective pepper seeds «Claudio» were used as plants. Plants were growing either with constant irradiation or with additional impulsive one. Measurements of plants growth parameters are conducted. According to the results of using of energy of optical measurements it is shown that plants use the larger part of energy for photosynthesis process, the smaller part - for warmth (heat) perception and unregulated process. It is shown that additional impulsive radiation leads to the increase of plants morphometric indices and concentration of chlorophylla $a$ and $b$ and carotenoids.
\end{abstract}

Key words: impulsive radiation, irradiation device, plants lightculture, pulse duration.

Statement of the problem. Light regime is important for growing plants in covered soil. At present, much attention is paid to the stationary or permanent illumination of plants $[1,2]$. Impulse radiation is also important for plants photoculture, but its effect on plants is still uninvestigated. Therefore, the investigation of the pulsed radiation influence is important.

Analysis of available investigations. This problem was investigated by many scientists [3 - 6], particularly the processes occurring in plants under the action of pulsed light were described in A.A. Shakhov's monograph [3]. At present, it has been established that prolonged pulsed radiation on the darkness background is ineffective, because induction losses are present in the transition from light to darkness. With such pulsed radiation, no positive effect was found on the storage of light energy through photosynthesis.

It is shown in S.A. Stanko's [4] paper that the pulsed light positively affects the synthesis and accumulation of sugar, amino acids and protein in plant leaves. It stimulates the synthesis of nucleic acids, which in turn results in increased metabolism.

It is noted in paper [4] that under the influence of pulsed light there is increase in the content of pigments and strengthening of chlorophyll and carotenoids bonds with the lipoidprotein complex in plant leaves. Its effect is to change the activity of photosynthetic apparatus by activating the pigments biosynthesis and photosynthesis stimulation.

The objective of the paper. Due to the appearance of light emitting diodes, which are energy-saving light sources with different spectral composition of radiation, it was possible to carry out experiments at a higher new level. In addition, LED light sources have very small constant afterglow, which makes it possible to use them as pulsed light sources.

Taking into account that the photosynthetic efficiency of radiation is concentrated in the blue and red areas, semiconductor light sources make it possible to carry out research, illuminating by light pulses, both in white and in each spectral areas, in particular. 
The task to investigate the influence of pulsed light sources on light crop of plants, depending on the conditions of exposure, was set up before the given work.

Description of the main material. To conduct the experimental research «Flora» type mini-greenhouses were used.

For constant lighting, the energy-saving compact fluorescent lamps (CFLs) of Osram Duluxstar 18W/840 type were used, as well as light-emitting diode light sources were assembled in the form of $0,3 \mathrm{~m} \times 0,3 \mathrm{~m}$ matrices. The matrix consisted of 192 red LEDs of MTK2-10R02WC-20cd type and 97 Blue LEDs of MTK2-5B02WC-2cd type with $20^{\circ}$ luminous angle of. For lateral irradiation, tapes with blue and red LEDs were used.

For pulsed irradiation, five LED matrices $0.3 \mathrm{mx} 0.3 \mathrm{~m}$ in size were also used. The first one consisted of 288 LEDs of white luminescence type, the second one - of the red LEDs of MTK2-10R02WC-20cd type and 97 blue LEDs of MTK2-5B02WC-2cd type, the third one - of 5 white, the fourth - of 5 blue10 W LEDs, and the fifth - of 5 red 10W LEDs.

Power supply of pulsed radiation sources was carried out by means of the developed power supply unit based on Attiny 13 microcontroller, controlling the power switches that supply electrical impulses to the light instrument. As power switches, $\mathrm{n}$-channel field transistors with $5 \mathrm{~V}$ control voltage were used. In order to control the LED operation, the «stroboscope» mode, where the LEDs included in one of seven programmed programs allowing to change both the pulse duration and pulse repetition rate were used. The selected program was stored in the internal memory of the microcontroller and was loaded during the voltage supply.

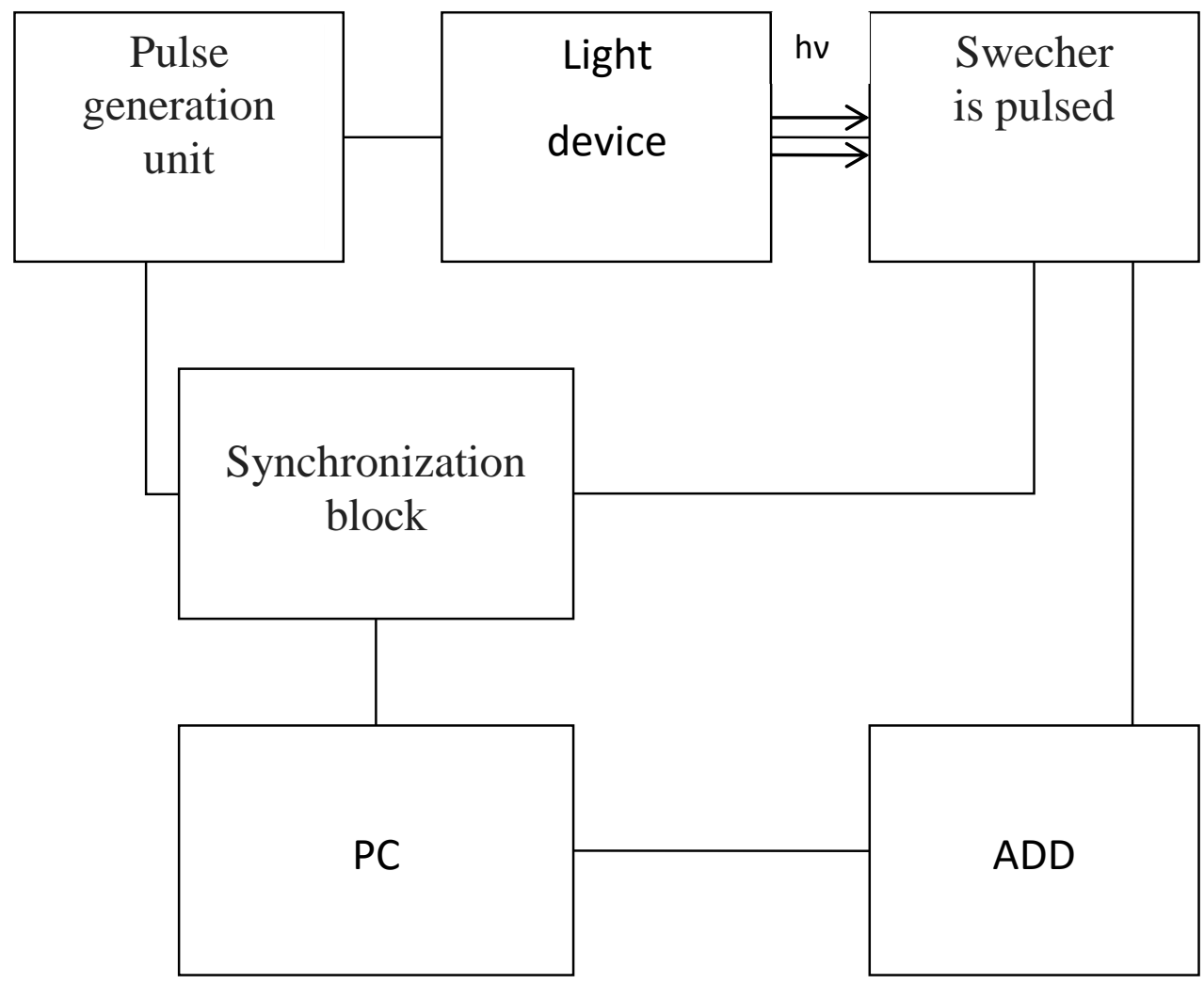

Figure 1. Block diagram of instalation for measurement of power parameters of impulsive light source 
Before using the LED pulsed radiators, their light pulses energy was measured. In order to do this a special installation was mounted. The block diagram of this installation is shown in Figure 1. It consists of the light instrument, the pulse generating unit, the synchronization unit, the pulsed candlemeter, ADD and PC.

The impulse voltage amplitude as well as pulse repetition rate and their duration was set by means of generating unit.

The light instrument is located on one optical axis with the input diaphragm of the pulsed candlemeter. The measurements results of via ADD were sent to the PC and entered into the database.

The level of illumination was measured by luxmeter of Ю 117 type and Solar Power Meter DT-1307.

Constant medium temperature and 16-hour exposure were maintained during the experiments.

Experiments were carried out with peppers of Claudio variety grown in three «Flora» mini-greenhouses.

2 CFL of Osram Duluxstar 18W/840 type operating in continuous mode and providing 3000 лк radiation level were used for lighting in the first (1) greenhouse. Control samples for comparative analysis were grown in it.

The second greenhouse (2) also used Constant irradiation produced by LED irradiation facility, consisting of: 192 red LEDs of MTK2-10R02WC-20cd type and 97 blue LEDs of MTK2-5B02WC-2cd with total capacity of $13.5 \mathrm{~W}$ was also used in the second greenhouse (2) and was installed above plants. In addition, they used 1 blue and 2 red LED strips, fixed on the side and back walls of the greenhouse.

2 CFL of Osram Duluxstar 18W/840 type were used as permanent exposure in the third greenhouse (3). LED matrix of white luminescence consisting of 288 LEDs of MTK2-4,8 type with $1 \mathrm{~ms}$ impulse duration and interval between pulses of $10 \mathrm{~s}$ was used for pulsed irradiation. Its power consumption is $17.3 \mathrm{~W}$.

After four-week growth period the raw and dry mass of plants was weighted, the concentrations of chlorophylls $a$ and $b$ and the major carotenoids were measured by means of extracting pigments by dimethylsulfoxide (DMSO) [7]. The concentration of chlorophylls $a$ and $b$ and the major carotenoids was determined by spectrophotometry using McKenneynArnon and Wettstein formulas [8].

Results of the investigation. Figure 2 shows Histograms of the indices of plants growth and morphometric parameters. Dry and raw pepper masses proved to be the best in the third greenhouse, where impulsed radiation was used on the background of constant irradiation. The same was observed with the concentration of chlorophyll $b$ and carotenoids. This indicates the positive effect of additional pulsed radiation on the plant growth and development.

For further research, the same mini-greenhouses and pepper plants were used, but the capacity of LI pulse-irradiation was increased by adding five $10 \mathrm{~W}$ white LEDs of. At the same time, the interval between flashes increased to $10 \mathrm{~s}$. 


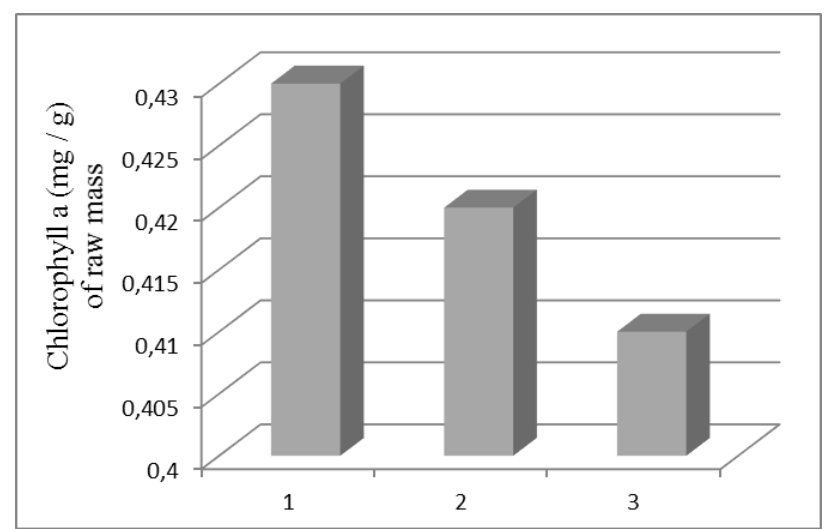

a)

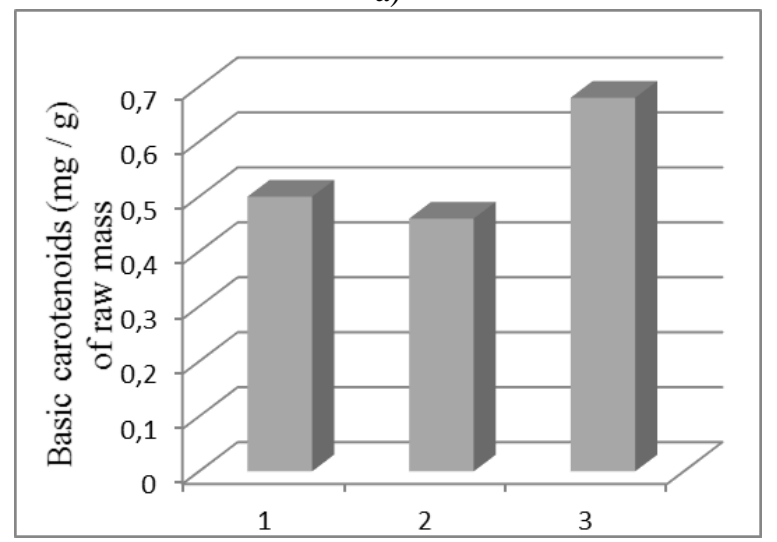

c)

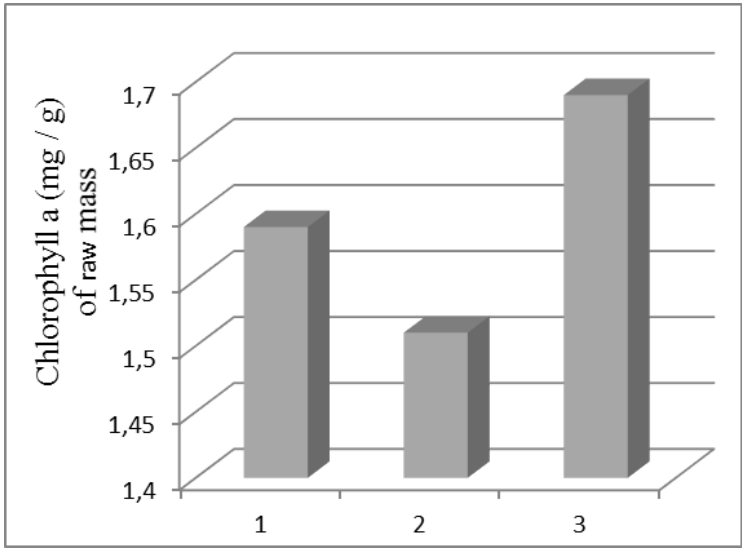

b)

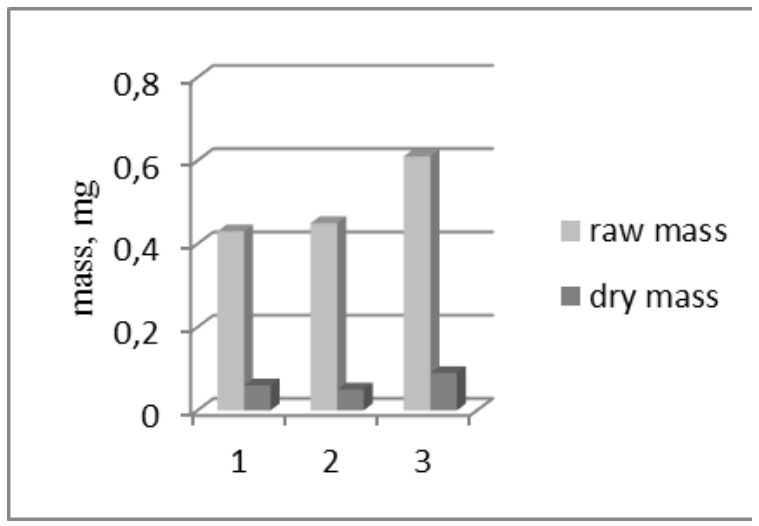

d)

Figure 2. Dependence of pepper's growing and morphometric indices: a) chlorophyll a; b)chlorophyll b; c)main carotenoids; d) biomass

The irradiation of the first mini-greenhouse remained unchanged, in the second greenhouse 2 CFL of Osram Duluxstar 18W/840 were added as constant irradiation, and the LED matrix was used in pulsed irradiation mode. In the third greenhouse constant irradiation remained unchanged, and LED irradiation unit consisting of $510 \mathrm{~W}$ LEDs of white luminescence with $16,38 \mathrm{~cd} \cdot \mathrm{s}$ illumination magnitude.

After 60 days of growth, the concentrations of chlorophyll $a$ and $b$ and the major carotenoids were measured. Biometric indices were also determined: dry and raw plant leaves mass, the area of the leaf surface (Figure 3). Indices of chlorophyll $a$ and $b$ were the best in the third greenhouse, where white pulsed radiation was used, the same trend was observed with raw and dry mass. The main carotenoids are higher in the first mini-greenhouse, and those grown in the third are in the second place. In general, while using additional pulsed lighting in the third mini-greenhouse pepper plants grew and developed faster and looked better than in the other two mini-greenhouses. 


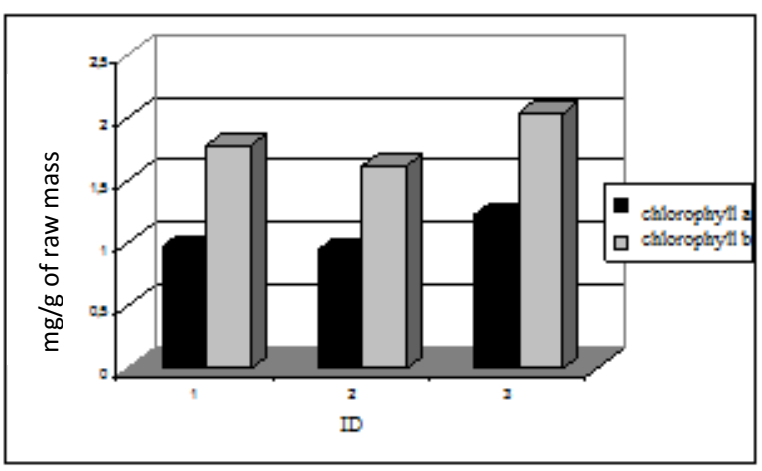

a)

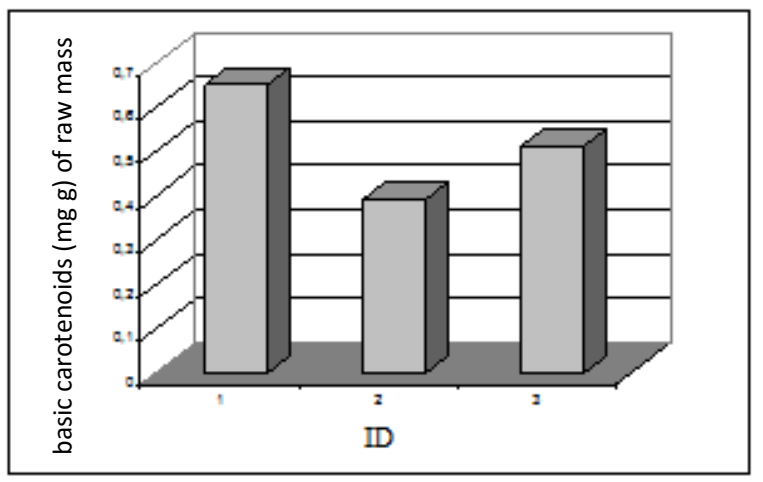

c)

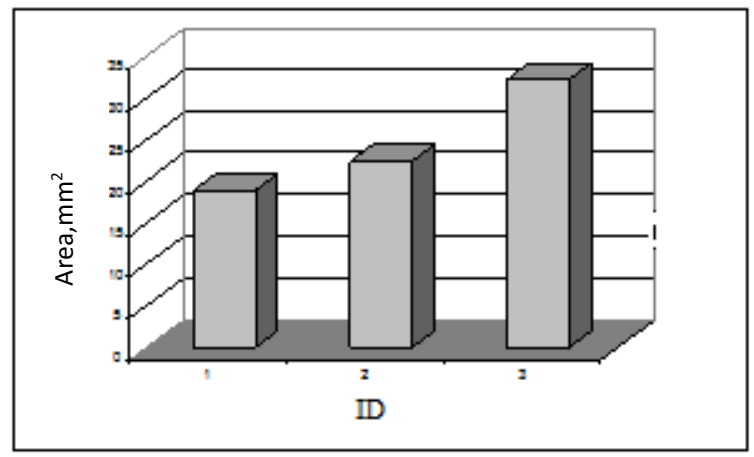

b)

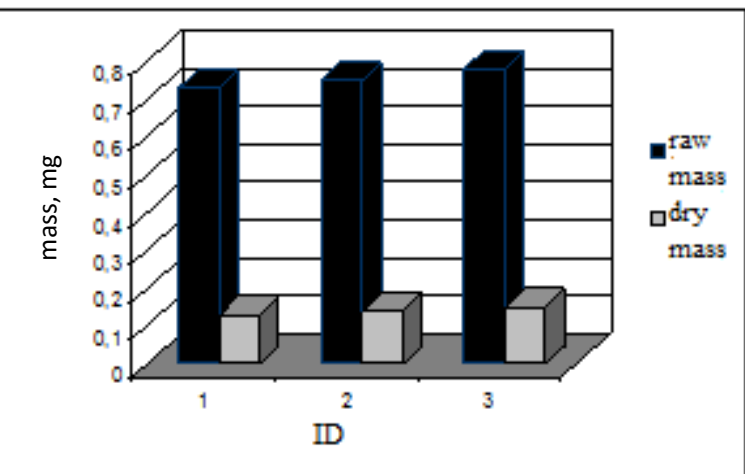

d)

Figure 3. Dependence of pepper's growing and morphometric indices: a) chlorophyll a and b, b) area, c) main carotenoids, d) biomass

In order to evaluate the efficiency of the optical radiation energy use while cultivating Claudio peppers under greenhouse conditions during the last 30 days, investigations characterizing the process of plants growth and development: photosynthetic efficiency of plants, unregulated processes occurring in plants, chlorophyll content and the perception of heat by plant, depending on the irradiation conditions were carried out (Figure 4). Relying on the fact that these three indicators are presented in relative units which sum should be equal to 1 , then changing one of them the others will change as well. For this purpose, MultispeQ fluorometer was used.

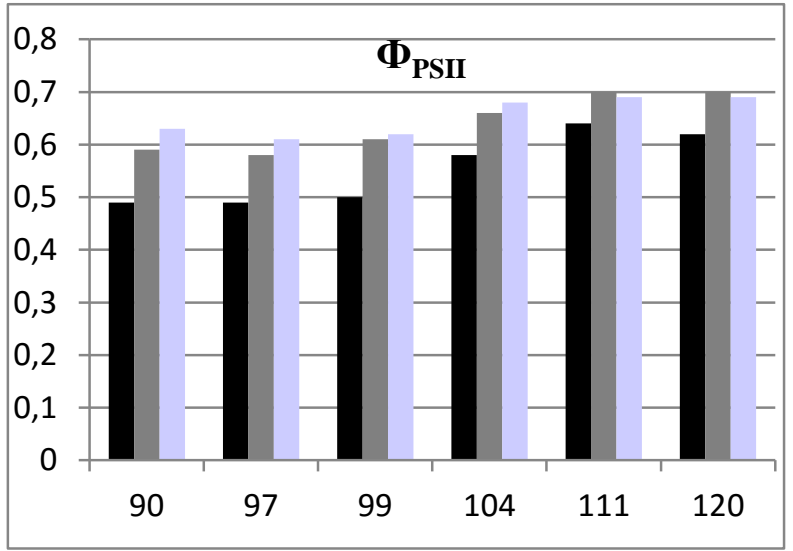

a)

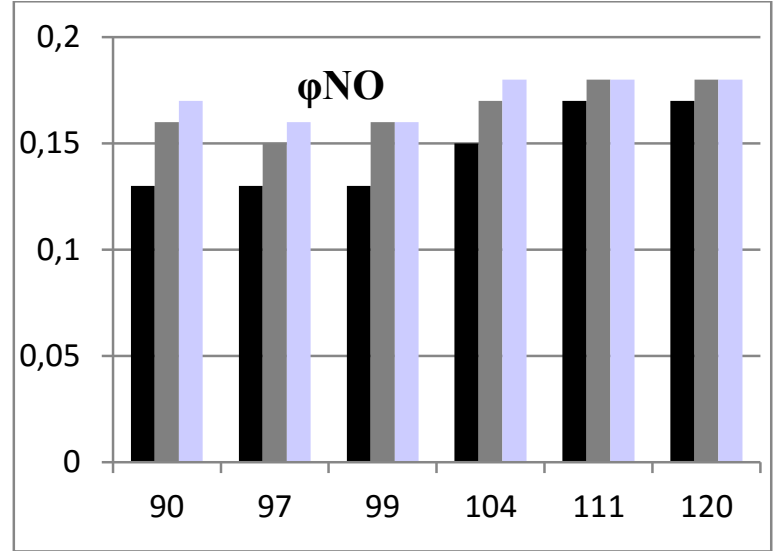

b) 


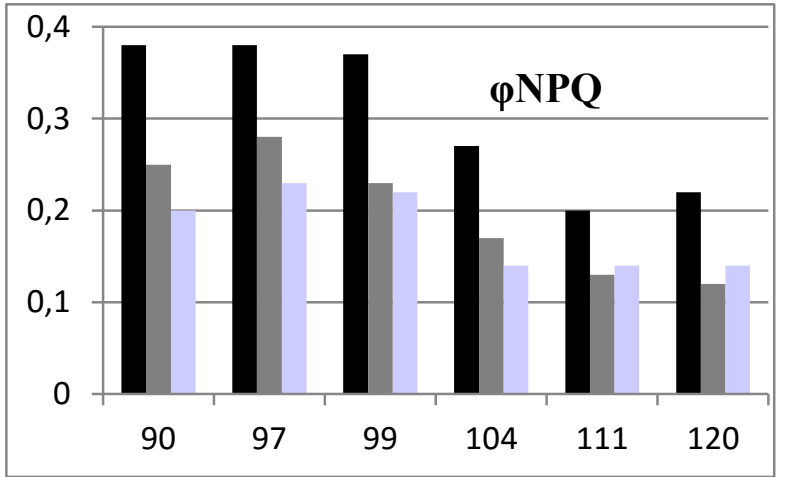

c)

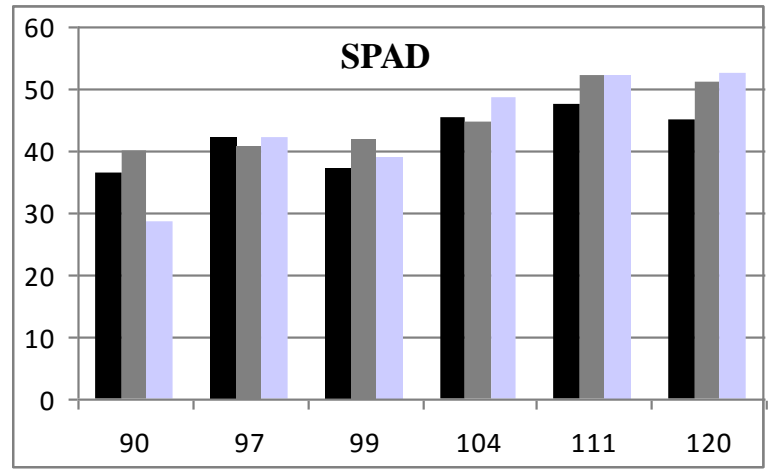

d)

$\square 2 \mathrm{CFL} \square 2 \mathrm{CFL}+$ white impulse $\square 2 \mathrm{CFL}+$ blue-red impulse

Figure 4. Change dynamics: a) photosynthetic activity; b) unregulated process; c) plant's warmth (heat) perception; d) chlorophyll content

The effectiveness of photosynthesis ( $\left.\Phi_{\text {PSII }}\right)$ is the proportion of light energy assimilated by plants characterizing the rate of formation of primary plant production in natural conditions. Expressed as the percentage of incident visible radiation converted into pure production during active photosynthesis. Unregulated processes $(\varphi N O)$, plant bypass slow down photosynthesis or are harmful for plants. This ratio indicates that part of the light energy which the plant loses inefficiently. $\varphi$ NPQ is the ratio which indicates the amount of light received by the plant, which is directed on non-chemical quenching. The latter reduces the damaging effects of excessive energy of light on photosynthetic apparatus. Relative content of chlorophylls (SPAD) parameter is widely used as an indicator of the plant nitrogen status.

Dynamics of changes in plant photosynthetic efficiency, unregulated processes occurring in plants, the content of chlorophylls and the plant heat perception depending on the conditions of radiation is shown in Figure 4. The investigations proved that the photosynthetic efficiency of $\Phi_{\mathrm{PSII}}$ is the best in the second and third mini-greenhouses where pulsed irradiation was used. The $\varphi$ NPQ inder is the best in the first mini-greenhouse, so the highest degree of plant heat perception is observed here. The highest energy inder that plants absorb and use in the process of photosynthesis is observed in the first greenhouse. The content of SPAD chlorophylls is determined both by using the MultispeQ fluorometer and by extracting the pigments DMSO are equally high in the third greenhouse confirming the results reliability.

Conclusions. 1. The radiation installation for light impulsed radiation of plants using LED light sources was designed and tested. 2. It is shown that additional impulse irradiation results in the growth of plants morphometric indices and concentration of chlorophylls $a$ and $b$ and carotenoids. 3. According to the results of the evaluation of optical radiation energy use by plants it is proved that the most part of the plant energy is used for photosynthesis processes, but less one for heat perception and unregulated processes.

\section{References}

1. http://4exam.info/book_283_glava_15_Lek\%D1\%81\%D1\%96ja_12_OPROM\%D0\%86NJUVALN\%D0 \%86_USTANOVKI_DLJA_ROSLIN.html

2. http://inb.dnsgb.com.ua/2006-1/06clsivs.html

3. Shakhov A.A. Teoreticheskiye aspekty preobrazovaniya svetovoy energii v impul'snom rezhime, Shakhov A.A. Svetoimpul'snaya stimulyatsiya rasteniy. M.: Nauka, 1971. [In Russian].

4. http://www.hortidaily.com/article/14697/Belgium-Gediflora,-grower-and-propagator-of-chrysanthemums, -delighted-with-phenomenal-LED-payback-time/

5. Zhandarbekova A.M. Vozdeystviye impul'snogo osveshcheniyarasteniy na ikh produktivnost', Zhandarbekova A.M., Poyezzhalov V.M., mnogoprofil'nyy nauchnyy zhurnal «intellect, idea, innovation - intellekt, ideya, innovatsiya» No 4, 2016, p. 260 - 264. [In Russian].

6. Stimulirushcheye deystviye impul'snogo kontsentrirovannogo solnechnogo sveta na semena i rasteniya, Stanko S.A. Svetoimpul'snaya stimulyatsiya rasteniy. M.: Nauka, 1971. [In Russian]. 
7. B.KH. Mezhunts Primeneniye dimetilsul'foksida $v$ kachestve rastvoritelya fotosinteticheskikh pigmentov $\mathrm{v}$ polevykh issledovaniyakh, Izvestiya gosudarstvennogo agrarnogo universiteta Armenii No 3, 2009, pp. 40 - 43. [In Russian].

8. Shlyk A.A. Opredeleniye khlorofillov i karotinoidov $\mathrm{v}$ yekstraktakh zelenikh list'yev. V kn.: «Biokhimicheskiye metody v fiziologii rasteniy». M.:Nauka, 1971. P. 154 - 157. [In Russian].

Список використаної літератури

1. http://4exam.info/book_283_glava_15_Lek\%D1\%81\%D1\%96ja_12_OPROM\%D0\%86NJUVALN\%D0 \%86_USTANOVKI_DLJA_ROSLIN.'̄tml

2. http://inb.dnsgb.com.ua/2006-1/06clsivs.html

3. Шахов, А.А. Теоретические аспекты преобразования световой энергии в импульсном режиме [Текст] / А.А. Шахов // Светоимпульсная стимуляция растений. - М.: Наука, 1971.

4. http://www.hortidaily.com/article/14697/Belgium-Gediflora,-grower-and-propagator-of-chrysanthemums, -delighted-with-phenomenal-LED-payback-time/

5. Жандарбекова, А.М. Воздействие импульсного освещения растений на их продуктивность [Текст]/ A.M. Жандарбекова, В.М. Поезжалов. Многопрофильный научный журнал «3i: intellect, idea, innovation - интеллект, идея, инновация». - № 4 - 2016. - С. 260 - 264.

6. Стимулирующее действие импульсного концентрированного солнечного света на семена и растения [Текст] / С.А. Станко / Светоимпульсная стимуляция растений. - М.: Наука, 1971.

7. Межунц, Б.Х. Применение диметилсульфоксида в качестве растворителя фотосинтетических пигментов в полевых исследованиях [Текст] / Б.Х. Межунц // Известия государственного аграрного университета Армении. - № 3. - 2009. - С. 40 - 43.

8. Шлык, А.А. Определение хлорофиллов и каротиноидов в екстрактах зелених листьев. В кн.: «Биохимические методы в физиологии растений» [Текст]/ А.А. Шлык. - М.:Наука, 1971. C. $154-157$.

УДК 628.979; 621. 273

\title{
ОСВІТЛЮВАЛЬНІ УСТАНОВКИ ДЛЯ СВІТЛОКУЛЬТУРИ РОСЛИН 3 ДОДАТКОВИМ ІМПУЛЬСНИМ ОПРОМІНЮВАННЯМ
}

\author{
Марія Котик $^{1}$; Володимир Андрійчук'; Андрій Герц ${ }^{2}$ \\ ${ }^{1}$ Тернопільський національний технічний університет імені Івана Пулюя, \\ Тернопіль, Україна \\ ${ }^{2}$ Тернопільський начіональний педагогічний університет \\ імені Володимира Гнатюка, Тернопіль, Україна
}

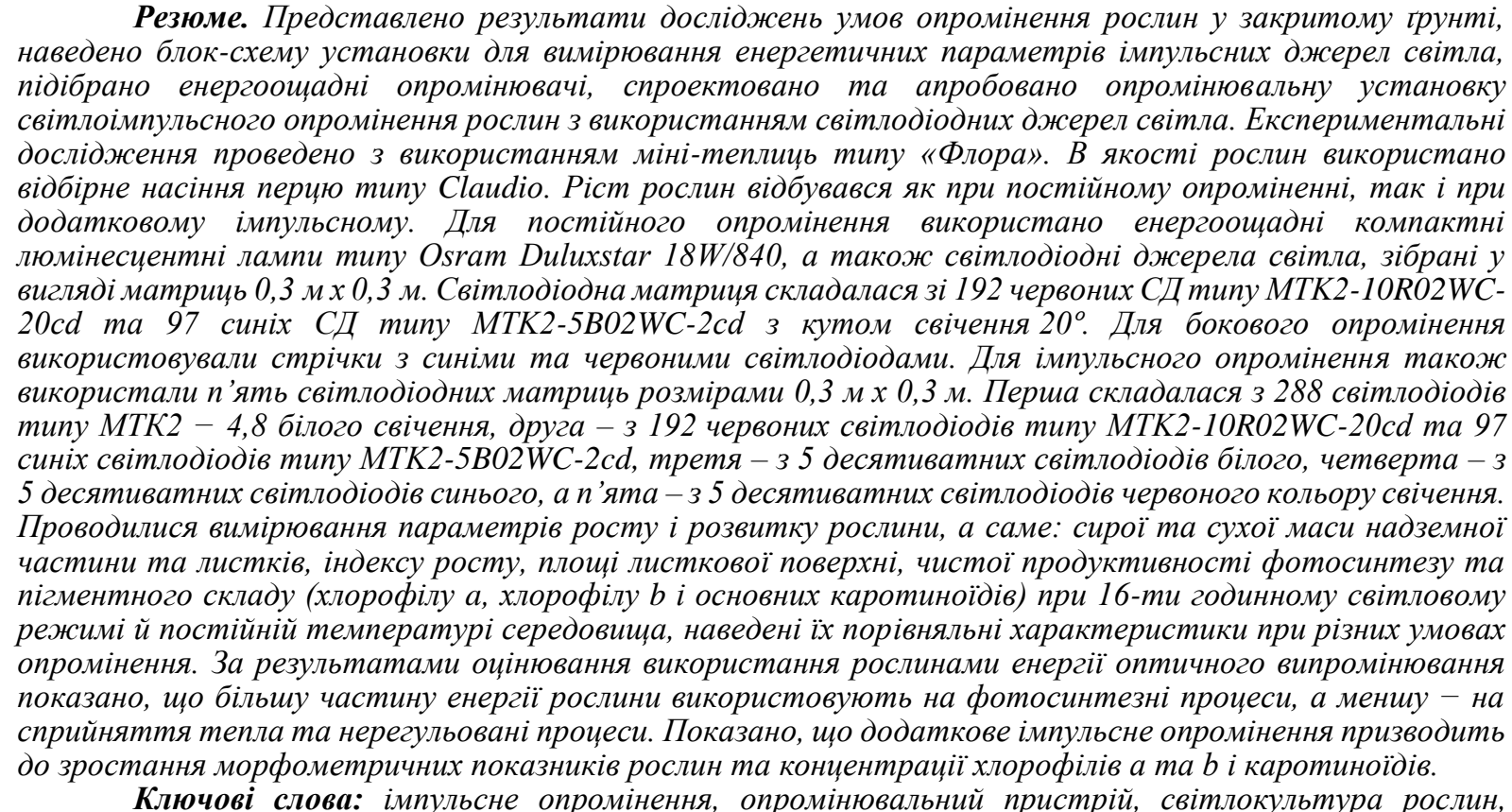
тривалість імпульсу. 